\title{
The Effectiveness of Adopting e-Learning during COVID-19 at Hashemite University
}

\author{
Alaa Obeidat ${ }^{1}$ \\ Hashemite University \\ Dept of basic Sciences \\ Zarqa, Jordan
}

\author{
Rana Obeidat $^{2}$ \\ Zarqa University \\ Faculty of Nursing \\ Zarqa, Jordan
}

\author{
Mohammed Al-Shalabi ${ }^{3}$ \\ World Islamic Sciences and Education \\ University \\ Amman, Jordan
}

\begin{abstract}
Learning is the utilization of the electronic technologies and the media to deliver the educational content to the learners, enabling them to interact actively with the content, the teachers, and their peers. Students' interaction can be either synchronous or asynchronous or a combination of both. One advantage of the e-learning is that learners can access the educational content at any place and time saving them effort, time, and cost. To deal with the unprecedented crisis of COVID-19 and the risk of virus transmission in the public, the vast majority of higher learning institutions globally were locked out and the delivery of the educational content moved from the traditional classroom teaching to the internet. The purpose of this study was to assess students' perceptions of the effectiveness of the e-learning during COVID-19 pandemic at the Hashemite University, Jordan. A total of 399 students completed the online survey of the study. Study results showed that students' overall evaluation of their elearning experiences were generally positive. However, students reported that they faced problems in the e-learning experiences of which most were related to technical issues (e.g., lack of a viable internet network, lack of laptops, etc.). Microsoft Teams was the platform most preferred by students for e-learning and the majority of students accessed the educational content using smart phones. Only gender and student's academic specialty had significant associations with their perceptions of the effectiveness of the e-learning.
\end{abstract}

Keywords-e-Learning; COVID19; classroom; ICT; Hashemite University; educational platform

\section{INTRODUCTION}

Information and Communication Technology (ICT) are vital to all aspects of everyday life in general and in education in particular. For its crucial role in creating an effective learning process and enhancing the role of learning, many educational institutions have adopted the use of ICT to continue with the process of educational communication. This transition from a traditional classroom to e- learning has also led to the emergence of new concepts within the world of education such as: e-learning, education through the internet, e-book, virtual university, e-library and other electronic media to allow the learner to learn according to personal preferences [1]. Learners can decide where and when they want to learn. They can prefer to learn without the commitment to attend classroom teaching at specific times. With the supply and accessibility of such modern technology in educational institutions, the integrated education using this technology has been designed and termed generally as e-learning.
e-Learning is not only an optimized use of both the human and material resources, but it also solves 'rare disciplines' problem. e-Learning makes it easy for the learner to communicate with any rare scientific discipline from anywhere in the world in no time. This is made possible as the training materials are prepared and made available by the educational institutions for those who need it. This is a low-cost solution to access and gain knowledge.

The deep-seated aspect to be considered before opting for e-learning is to check the feasibility for this adoption and investment. It would help to circumvent hurdles and troubles while transitioning traditional mode to information technology. Proper consideration is required to manage the resistance to change, aversion to transition and implement the change effectively [2]. To develop a successful e-learning strategy, such a system should be selected and developed appropriately that fulfills the requirements of education including constant updates to remain well-informed about the developments, observing standards and controls within the chosen education system to make sure that the level and development of the learner is under way and educational and non-educational goals are accomplished.

Information technology should not be mistaken for a goal. Rather, it is a way of communicating knowledge that is adopted and employed to achieve the purposes of education, and to enable the learner to combat the requirements of work-life with all its facets, which are becoming more dependent on information technologies and are evolving frequently.

\section{A. Types of e-Learning}

- Simultaneous Delivery

In this type, lecturer and students (learners) in different educational institutions such as universities, institutes and schools, communicate and interact directly at any real time. This mode can also be termed as synchronous and can be employed to conduct distance learning and some training courses.

\section{- Asynchronous Delivery}

In this type, the lecturer makes the course material available on videotapes, or transfers the contents via a computer or any other mean. While the student (the recipient) from the other side, receives the material at a later time suitable and feasible for him [3]. 


\section{B. Distance Learning Goals}

In line with the general aims of the education, distance learning aims to provide much more [4]. It promises:

1) Provision of educational opportunities for those who are deprived of these chances at all levels for many reasons that may include political, geographic, economic or social to name a few. Primarily, the distance education is to facilitate those ambitious learners who are striving to develop and educate themselves and to improve the educational, social and professional levels.

2) Creating apposite educational conditions to suit and cater to the needs of learners to aid continuous learning.

3) Providing the learners with the flexible schedule to fit to the conditions and circumstances for varied students such as housewives, farmers, industrialists and employees.

4) Redefining education, yet keeping it compatible with the provision of knowledge and the scientific and technological revolution in the present era. This new concept of education must enable the individuals to achieve competence through continuous education and self-learning. The idea of 'anytime, anywhere' learning is the need of the time, so that the students can learn at the moment they want it using the technology they prefer which is different from a traditional classroom and lecture hall environment.

5) Introducing new specialties that society needs, but traditional college systems do not allow and support to achieve.

6) Providing all citizens with cultural programs and knowledge. The benefits of information and communication technology are not just limited to students only, but all citizens can get benefits. It is possible because of the modern means of communication for example, television and satellites and using them to broadcast educational programs through them.

\section{Elements of Distance Learning}

To start with, distance learning requires the availability of the internet to facilitate communication with the student or learner present and responsible to track everything related to the educational material. Specially designed sites and portals following an appropriate mechanism can be used to achieve the purpose. These sites and portals should explain the material in an easy to understand manner so that they can be proved beneficial. Discussion forums, both direct and indirect, can also be made available to the teacher and the student. Lastly, teacher who has been assigned the responsibility to monitor and evaluate the student's performance must be available and must award marks to the student that he deserves.

\section{Distance Learning Methods}

There exist many methods of distance learning, and each of these methods target a specific stage of the educational interaction during the development of distance learning. Development in information and communication technology is taking place at a huge pace. This development and evolution is reflected in its educational uses that are expanding. New and more effective methods of distance learning are emerging [5] [6]. Among the most proven methods for distance learning include:

\section{- Multimedia Style:}

This method is based on written communication. Learners make use of the written material provided to them through audio and video recordings on CDs or the phone and radio broadcasting. Educational references, study guides and systematic books are printed and provided to the learners. Multimedia style can not only be adopted to support distance learning on its own but it also provides substantial support to other methods as well.

\section{- Video Conferencing Method:}

As it is stated in [7], this method is same as the learning happening in a traditional classroom. However, learners are geographically distant from their teachers and colleagues and connected via high-speed communication channels. Everyone can see and listen to the teacher. They can ask direct questions. They can actively participate in a discussion and can interact with the topic presented by the teacher. But to ensure everything goes well and as planned, the video conferencing method requires prior planning and preparation and takes longer time as compared to a traditional class lecture. It also demands scientific material and media. Teachers should be trained to attain student's attention and interest. All these are prerequisites to make effective use of this technology.

\section{LITERATURE REVIEW}

\section{A. e-Learning}

e-Learning is a new form to learn and communicate and it employs new computing technologies with high speed networks. It facilitates to develop skills, learn distantly and collaborate globally. These emerging technologies have evolved and transformed the learning and the processes and environments involved in learning. Author in [8] defines e-learning as the use of web-based technology tools along with the materials available on CDs, the internet, video and audiotapes and TV Broadcasts. Whatever tool it may use, main objective of elearning is to provide a learning opportunity for individuals. [9] Looks for a single definition of e-learning which does not exist due to the different perspectives and constant evolution of this concept. e-Learning is found to be an amalgamation of various disciplines including data communication, computer science and pedagogy. So, the e-learning must be defined in the vast terms. Author describes e-learning as far more than just the technology and considers four main categories while defining it: "technology, delivery systems, communication, and educational paradigms”.

\section{B. e-Learning during COVID-19}

COVID-19 pandemic led to the emergency closure of the educational institutions all around the world. To continue the learning process employing e-learning and online classes is a real challenge for governments and academic institutions. The author in [22] explains how lack of technical support, awareness, readiness, skills, resource materials and infrastructure pose challenges to the adoption of e-learning. Trust issues, resistance to accept the change and financial issues are also critical to the success of e-learning programs. 


\section{Effectiveness and Adoption of e-Learning among the Learners and Teachers}

S. Bell, B. \& E. Federman, J [10] explains the widespread use of ICT in recent and future years. Authors declare that comparing e-Learning's effectiveness with a traditional classroom is an old research topic. Focus should now be shifted towards making this mode of learning more effective and enhancing its features. Future research and advancements should modify the design model of e-learning system to overcome existing barriers and widespread the use and adoption of "online instruction" across cultural and geographical boundaries. Author in [11] examines the factors that impact the adoption of the e-learning programs and it is found that adoption is decided by some factors including: "relative advantages, trial ability, and academic specialization”. Positive relative advantage increases the adoption rate for new systems and technologies. If the teachers are given a chance to test the tools and technology before implementation, they feel more confident and thus adoption rate improves. Further, the faculty from IT-oriented departments is found to be more welcoming to adopt new technologies. Study finds age and experience irrelevant to the adoption rate which is conflicting with many existing researches. Author in [12] identifies underlying factors that influence students' intentions to use new learning technologies involving collaborative features. The enhanced model declares peer influence, ease of use, compatibility with existing tools and practices significantly affect the adoption rate.

In higher-education, e-readiness is considered as a critical factor for the success of e-learning programs. Author in [13] discusses the e-readiness factors and improvement of those factors to make e-learning more effective. The study discovers skills and attitudes as the most crucial factors influencing elearning readiness. Author in [14] acknowledges that in an online class, students may find it difficult to communicate with other students, faculty and administration. Even some students isolate themselves or somewhat feel isolated. They don't come forward and ask for any assistance on their own. Students face challenges in interaction and collaboration in an online classroom because of absence of fact-to-face and a nonverbal communication. Students don't feel themselves really connected. Talking about the advantages, while planning for online learning programs, curriculum can be designed keeping a particular student in mind. Study finds that to ensure connectivity and engagement in an online class, focus should be on building trust, showing presence, encouraging teamwork, and improving personal contact.

Declares e-learning as a new era in education which has revolutionized thoughts, enhanced existing educational and training models where the learner occupies a central and pivotal position [15]. Although ICT has its own disadvantages and limitations, but it emphasizes on learning that is independent, flexible, interactive and fits in with the time and pace of a learner. To adopt this mode in more effective way, infrastructure must be improved. Author in [16] finds e-learning truly effective when it incorporates and caters to the individual needs of the learner. In such an environment, online learners' exhibit enhanced capabilities and more organized thinking processes when they are given individualized instruction. Author in [17] studies the impact of various factors on the effectiveness of e-learning. Factors like the level of education, age, study program and gender are found to have significant influence on the success of e-learning. However, some factors are found to be irrelevant including race and marital status. It is indicated that learners enrolled in high level of education accept this new mode of learning easily and contribute towards its effectiveness. While considering the gender, female learners are found to be more patient and benefit more from the e-learning programs.

Discusses the factors that define and determine the success and effectiveness of e-learning [18]. Paper declares the use and user satisfaction of e-learning as closely linked. The user satisfaction is found to be related to quality of resource material and system, teacher attitude, evaluation and assessment methods, and learner's interaction with peers and the teacher. Use of e-learning is more effective when quality of collaboration and content, and above all, user satisfaction are improved. Technology should be employed to ensure collaborative environment. Similarly, the information quality also significantly improves the e-learning programs. Contents that are accessible, useful, easy to understand and authentic enhance the use and the user satisfaction. Assessment can be done in a variety of ways like using quizzes and tests. Similarly, overall success of the program can be made possible by improving these factors. e-Learning programs can be made more effective and successful if they take into consideration the individual requirements and interest of the learners. Author in [19] proposes that e-learning can only be made personalized with deliberate efforts to fit in to the needs, objectives, interests, and abilities of a learner. This paper recommends a programmed online tutoring system which adapts itself automatically to the interests and abilities of the learners. For the purpose, this personalized e-learning system records the knowledge, learning style, choices and objectives of an individual leaner. Author in [20] presents a six-dimensional integrated model for elearning discovering factors affecting the user satisfaction. These dimensions include: "learners, instructors, courses, technology, design, and environment." Study concludes that uneasiness of learner with the electronic gadgets, teacher's mind-set towards e-learning, course flexibility and quality, navigation complexity, variety of ways to assess and evaluate the learner are the factors that must be focused to improve the e-learning programs.

Discusses about the failures of e-learning portals and initiatives in developing countries [21]. Reasons behind the failure are found to include lack of technical knowledge, not-easy-touse systems and technologies, ineffective marketing, and insufficient training and support. Mainly, the study finds that failure is not because of technology or its availability. Rather, the improper use of technology causes the failure. e-Learning systems are failing to satisfy the users for not serving the purpose they were developed for. Paper also discusses possible way out to improve the system. 


\section{Study Purpose and Research Questions}

This study aimed to assess students' perceptions of the effectiveness of the e-learning during COVID-19 pandemic at the Hashemite University, Jordan. The study was conducted to answer two research questions:

$\boldsymbol{R Q}$ 1: What is the level of effectiveness of using E- learning during the era of COVID-19 at the Hashemite University?

$\boldsymbol{R Q} 2$ : Are there statistically significant differences in the responses of the study sample individuals to the effectiveness of using e-learning during the COVID-19 era at the Hashemite University according to the variables (e.g., gender, student's academic year, specialization, place of residence, GPA, branch of education in the Tawjihi)?

\section{Materials AND MethodS}

A cross-sectional survey research design was used to answer the research questions of this study. A total of 399 students from different academic fields at the Hashemite University, Jordan were conveniently recruited and completed the study survey. An online survey (i.e. Google forms) was used to collect data from the study respondents. Students were invited to the study using different social media and platforms (e.g., Facebook, university website). The online survey was composed of three parts: a study cover letter, a demographic data sheet and a questionnaire about students' perceptions about e-learning. The study cover letter contained information about the purpose of the study, risks and benefits, assurance of keeping students' information confidential, and contact information of the researcher. Students' completion of the online survey was considered their consent to participate in the study. The questionnaire contained a total of 19 items which asked about students perceptions related to the impact of distance learning process, the amount of time each student spends on different platforms, any challenges students faced in the elearning process, and their attitudes toward the potential continuation of the e-learning in the next 6 months if the COVID19 pandemic did not come to an end. Students were asked to indicate their agreement with each of the 19 statements in the questionnaire using a Liker scale ranging from 1 (strongly disagree) to 4 (strongly agree). Data were analyzed using the Statistical Package for Social Sciences (SPSS). Descriptive (i.e. means, standard deviations, and frequencies) and inferential statistics (t test and one-way analysis of variance) at a significance level of .05 were calculated as appropriate.

\section{RESULTS}

\section{A. Statistical Standard}

Lecture quadrant is approved to correct the study tools, by giving each of its paragraphs one of the four degrees (strongly agree, agree, disagree, strongly disagree) and they are digitally represented $(4,3,2,1)$ respectively, and it has been done. To analyze the results, the following scale is adopted:
The following formula is used to calculate the scale:

Upper limit for scale (4) - Lower limit for scale (1)/ Number of required categories ( 3 )

(4-1) $/ 3=1$

Then add the answer (1.00) to the end of each category.

\section{B. The Study Sample}

The sample of the study is distributed (see Table I).

TABLE I. FREQUENCIES AND PERCENTAGES

\begin{tabular}{|c|c|c|c|}
\hline Variables & Categories & Frequency & Percent \\
\hline \multirow{5}{*}{$\begin{array}{l}\text { Student's school } \\
\text { year }\end{array}$} & First & 110 & 27.6 \\
\hline & Second & 92 & 23.1 \\
\hline & Three & 91 & 22.8 \\
\hline & Fourth & 97 & 24.3 \\
\hline & Fifth & 9 & 2.3 \\
\hline \multirow{9}{*}{ Specialization } & Medicine & 65 & 16.3 \\
\hline & Languages & 53 & 13.3 \\
\hline & $\begin{array}{l}\text { Medical and health } \\
\text { sciences }\end{array}$ & 40 & 10.0 \\
\hline & Engineering & 11 & 2.8 \\
\hline & Sport & 38 & 9.5 \\
\hline & $\begin{array}{l}\text { College of Education } \\
\text { with its specializations }\end{array}$ & 23 & 5.8 \\
\hline & $\begin{array}{l}\text { College of Sciences with } \\
\text { its specializations }\end{array}$ & 20 & 5.0 \\
\hline & $\begin{array}{l}\text { Information technology } \\
\text { with specializations }\end{array}$ & 7 & 1.8 \\
\hline & Others & 142 & 35.6 \\
\hline \multirow{2}{*}{ Sex } & Male & 137 & 34.3 \\
\hline & Female & 262 & 65.7 \\
\hline \multirow{3}{*}{ Address } & City & 317 & 79.4 \\
\hline & Village & 74 & 18.5 \\
\hline & Camp & 8 & 2.0 \\
\hline \multirow{4}{*}{ GPA } & Less than 2 & 7 & 1.8 \\
\hline & 2- 2.5 & 70 & 17.5 \\
\hline & $2.6-3$ & 129 & 32.3 \\
\hline & $3.1-4$ & 193 & 48.4 \\
\hline \multirow{4}{*}{$\begin{array}{l}\text { Academic branch } \\
\text { in Tawjihi }\end{array}$} & Literary & 156 & 39.1 \\
\hline & Scientific & 174 & 43.6 \\
\hline & Industrial & 17 & 4.3 \\
\hline & Others & 52 & 13.0 \\
\hline \multicolumn{2}{|l|}{ Total } & 399 & 100.0 \\
\hline
\end{tabular}

- 0.00 through 2.00 is low

- 2.01 through 3.00 is average

- 3.01 through 4.00 is high 


\section{First: Descriptive Analysis of the Study Tool}

For the estimates of the study sample individuals on the effectiveness of using e-learning during the COVID-19 pandemic at the Hashemite University to indicate the level of their response to the items of the tool, the arithmetic averages and standard deviations are calculated.

See Table II, it shows the arithmetic averages between 1.87 and 3.14. Paragraph Number (10) which states, "There are problems that I face during distance learning, most of which are technical" comes in the first place with an arithmetic average of (3.14), and Paragraph Number (7), which states "Distance learning helped me to understand the material in a way more than the traditional method," appears last, with an arithmetic average of (1.87), and the arithmetic mean of the tool as a whole was (2.37).Thus, the majority of the students agreed that using e-learning programs during the era of COVID-19 is effective on average.

TABLE II. ARITHMETIC AVERAGES AND STANDARD DEVIATIONS ARRANGED IN DESCENDING ORDER ACCORDING TO AVERAGES

\begin{tabular}{|c|c|c|c|c|c|}
\hline Rank & No. & Items & Mean & $\begin{array}{l}\text { Std. } \\
\text { Deviation }\end{array}$ & Level \\
\hline 1 & 10 & $\begin{array}{l}\text { There are prob- } \\
\text { lems that I en- } \\
\text { counter during } \\
\text { distance learning, } \\
\text { most of which are } \\
\text { technical }\end{array}$ & 3.14 & .715 & High \\
\hline $\begin{array}{l}3 . .3 .0 \\
2\end{array}$ & 11 & $\begin{array}{l}\text { I can ask ques- } \\
\text { tions during the } \\
\text { distance learning } \\
\text { and get my an- } \\
\text { swers }\end{array}$ & 2.90 & .733 & Average \\
\hline 3 & 1 & $\begin{array}{l}\text { Ican access the } \\
\text { electronic lectures } \\
\text { easily }\end{array}$ & 2.64 & .850 & Average \\
\hline 4 & 3 & $\begin{array}{l}\text { Provides technical } \\
\text { support from the } \\
\text { university in the } \\
\text { event of a tech- } \\
\text { nical problem }\end{array}$ & 2.63 & .775 & Average \\
\hline 5 & 12 & $\begin{array}{l}\text { Distance learning } \\
\text { helped me en- } \\
\text { hance my self- } \\
\text { learning ability }\end{array}$ & 2.62 & .897 & Average \\
\hline 6 & 4 & $\begin{array}{l}\text { The electronic } \\
\text { content displayed } \\
\text { for the material is } \\
\text { sufficient appro- } \\
\text { priate }\end{array}$ & 2.54 & .850 & Average \\
\hline 7 & 16 & $\begin{array}{l}\text { Distance learning } \\
\text { was a way to } \\
\text { focus more on } \\
\text { studying because } \\
\text { it provided time to } \\
\text { go to university }\end{array}$ & 2.49 & 1.034 & Average \\
\hline 8 & 6 & $\begin{array}{l}\text { Lectures include } \\
\text { assignments and } \\
\text { exercises that } \\
\text { facilitate the } \\
\text { understanding of } \\
\text { the material }\end{array}$ & 2.48 & .789 & Average \\
\hline
\end{tabular}

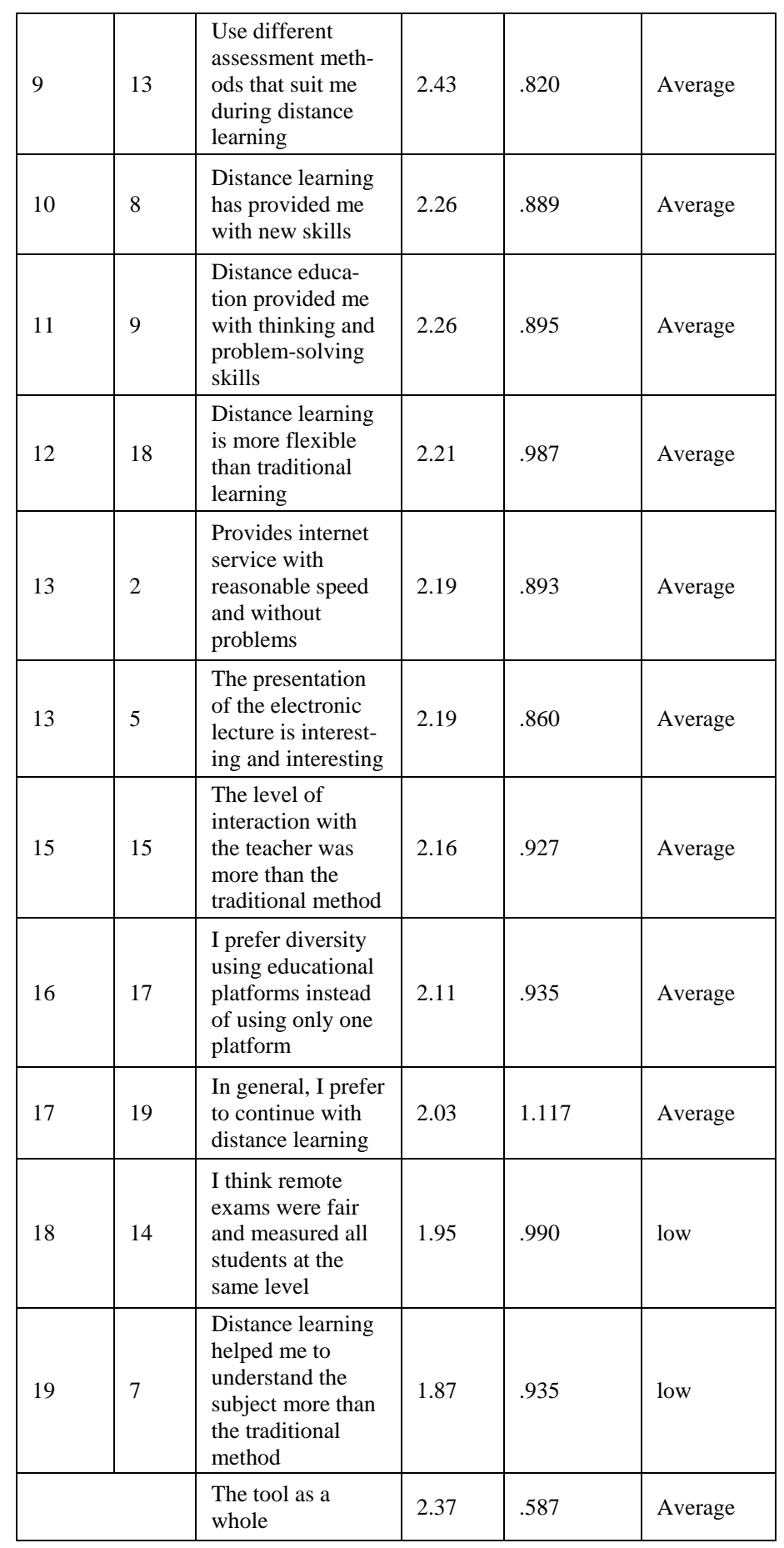




\section{Second: Questionnaire questions}

1) From your point of view, which of the learning platforms is the best and least technical problem?

As shown in Fig. 1 and Table III that the students prefer to use MS Teams as medium of communication more than the other tools. form?

2) What is the method used to access the learning plat-

As shown in Fig. 2 and Table IV that the students prefer to smart phones to access to the different educational platforms and to download the courses materials.

\section{E. Third: Finding Statistically Significant differences At- tributable to Demographic Variables}

Arithmetic averages and standard deviations are extracted for the responses of the study sample in the effectiveness of using e-learning during the era of COVID-19 in the Hashemite University according to variables (gender, student's school year, specialization, place of residence, grade point average, and academic branch in the guideline), and Table $\mathrm{V}$ shows that.

Table V shows significant statistical differences at the significance level $(p=0.05)$ due to the effect of gender on the responses of the study sample on the effectiveness of using elearning during the COVID-19 pandemic at the Hashemite University, and the differences appear in favor of males.

Table VI shows a clear variation in the arithmetic averages and standard deviations of the study sample responses in the effectiveness of using e-learning during the COVID-19 era at the Hashemite University due to the different categories of variables (the student's school year, specialization, place of residence, GPA, branch of Tawjihi). To illustrate the significance of the statistical differences between the arithmetic averages, the five-way variance analysis is used according to (See Table VI).

It is clear from the Table VII that there exist no significant statistical differences at the level of significance ( due to the variables: the student's school year, place of residence, grade point average, and academic branch in the Tawjihi.

It is also found that there are present significant statistical differences at the level of significance (

variable of study on the responses of the study sample in the effectiveness of using e-learning during the era of COVID-19 in the Hashemite University, and to show the significant statistical differences between the arithmetic averages, the dimensional comparisons are used in an oral manner as shown in the Table VII.

Table VIII it is apparent that there are considerable statistical differences $(p=0.05)$ between the specialty of languages and others on the one hand and the specialty of medicine on the other hand, and the differences come in favor of the medicine specialty.

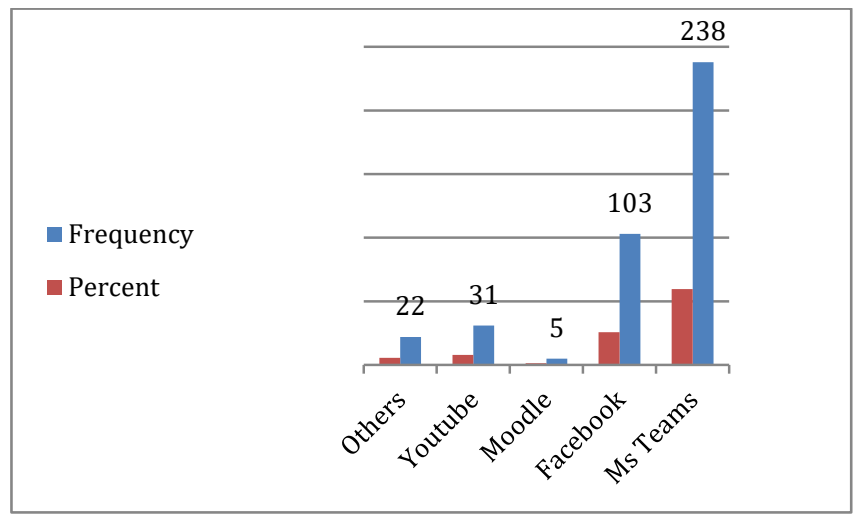

Fig. 1. Educational Platforms Preferences.

TABLE III. FREQUENCIES AND PERCENTAGES ACCORDING TO THE RESPONSE REGARDING PLATFORMS

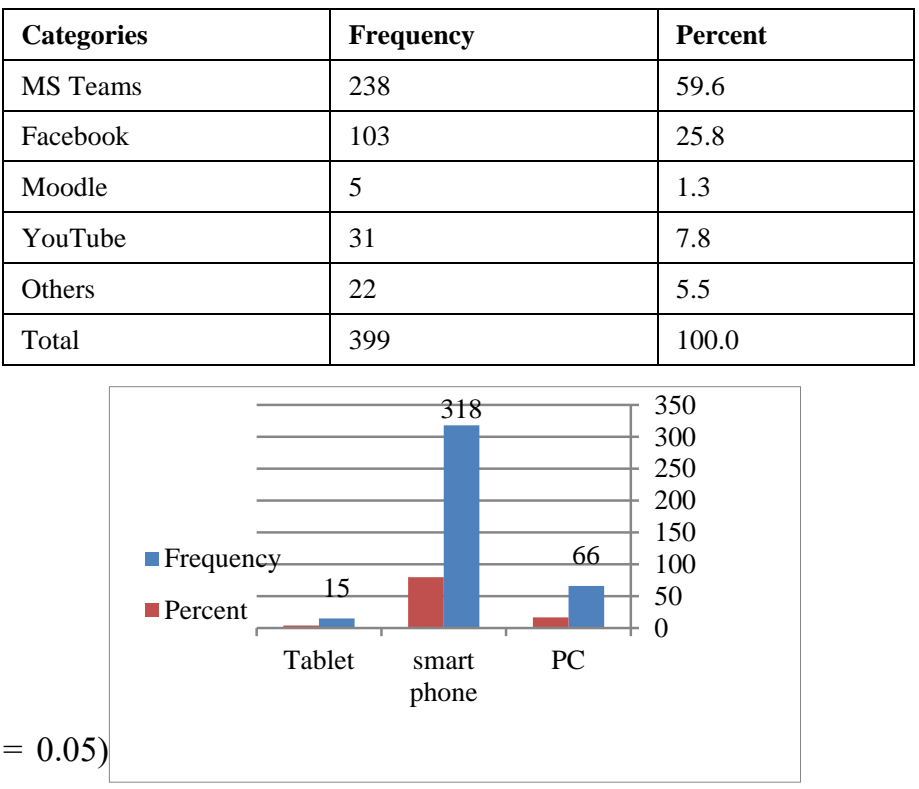

Fig. 2. Hardware Tool to Access the Platforms.

TABLE IV. FREQUENCIES AND PERCENTAGES ACCORDING TO THE RESPONSES REGARDING HARDWARE TOOLS

\begin{tabular}{|l|l|l|}
\hline $\begin{array}{c}\text { O.05) due to the } \\
\text { Categories }\end{array}$ & Frequency & Percent \\
\hline PC & 66 & 16.5 \\
\hline Smart Phone & 318 & 79.7 \\
\hline Tablet & 15 & 3.8 \\
\hline Total & 399 & 100.0 \\
\hline & & \\
\hline
\end{tabular}


TABLE V. AVERAge, Standard DeViations AND T-Test For SEX IMPACt

\begin{tabular}{|l|l|l|l|l|l|l|l|}
\hline Variable & Categories & $\mathbf{N}$ & Mean & Std. Deviation & t & Df & Sig \\
\hline \multirow{2}{*}{ Gender } & Male & 137 & 2.51 & .636 & 3.499 & 397 & $.001^{*}$ \\
\cline { 2 - 8 } & Female & 262 & 2.30 & .547 & & & \\
\hline
\end{tabular}

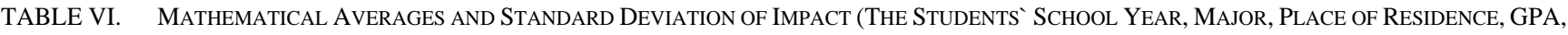
BRANCH OF TAWJIHI))

\begin{tabular}{|c|c|c|c|c|}
\hline Variable & Categories & $\mathbf{N}$ & Mean & Std. Deviation \\
\hline \multirow[t]{5}{*}{ Student's school year } & First & 110 & 2.34 & .524 \\
\hline & a second & 92 & 2.46 & .562 \\
\hline & Three & 91 & 2.31 & .616 \\
\hline & Fourth & 97 & 2.37 & 632 \\
\hline & Fifth & 9 & 2.45 & .759 \\
\hline \multirow[t]{9}{*}{ Specialization } & Medicine & 65 & 2.68 & .494 \\
\hline & Languages & 53 & 2.26 & .510 \\
\hline & Medical and health sciences & 40 & 2.28 & .509 \\
\hline & Engineering & 11 & 2.19 & .570 \\
\hline & Sport & 38 & 2.51 & .720 \\
\hline & College of Education with its specializations & 23 & 2.34 & .505 \\
\hline & College of Sciences with its specializations & 20 & 2.47 & .702 \\
\hline & Information technology with specializations & 7 & 2.52 & .939 \\
\hline & Others & 142 & 2.27 & .565 \\
\hline \multirow[t]{3}{*}{ Address } & City & 317 & 2.39 & .584 \\
\hline & Village & 74 & 2.30 & .608 \\
\hline & Camp & 8 & 2.30 & .535 \\
\hline \multirow[t]{4}{*}{ GPA } & Less than 2 & 7 & 2.65 & .346 \\
\hline & $2-2.5$ & 70 & 2.48 & .732 \\
\hline & $2.6-3$ & 129 & 2.34 & .573 \\
\hline & $3.1-4$ & 193 & 2.35 & .539 \\
\hline \multirow[t]{4}{*}{ Academic branch in Tawjihi } & Literary & 156 & 2.23 & .537 \\
\hline & Scientific & 174 & 2.48 & .556 \\
\hline & Industrial & 17 & 2.57 & .739 \\
\hline & Others & 52 & 2.38 & .694 \\
\hline
\end{tabular}

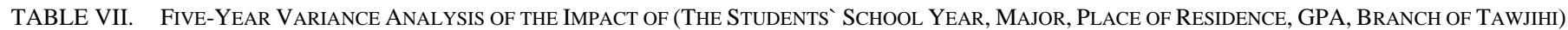

\begin{tabular}{|c|c|c|c|c|c|}
\hline & Type III Sum of Squares & df & Mean Square & $\mathbf{F}$ & Sig. \\
\hline Student's school year & 1.446 & 4 & .362 & 1.130 & .342 \\
\hline Specialization & 7.882 & 8 & .985 & 3.081 & $.002 *$ \\
\hline Address & .439 & 2 & .220 & .687 & .504 \\
\hline GPA & 2.040 & 3 & .680 & 2.126 & .096 \\
\hline Academic branch in Tawjihi & 1.318 & 3 & .439 & 1.374 & .250 \\
\hline The error & 120.894 & 378 & .320 & & \\
\hline Kidney & 137.134 & 398 & & & \\
\hline & & & & & \\
\hline
\end{tabular}


TABLE VIII. DimENSIONAL COMPARISONS IN A HEALING MANNER TO THE EFFECT OF SPECIALIZATION

\begin{tabular}{|c|c|c|c|c|c|c|c|c|c|}
\hline Categories & Medicine & Languages & $\begin{array}{l}\text { Medical } \\
\text { and Health } \\
\text { Sciences }\end{array}$ & Engineering & Sport & $\begin{array}{l}\text { College of } \\
\text { Education: } \\
\text { Specializations }\end{array}$ & $\begin{array}{l}\text { College of } \\
\text { Sciences: } \\
\text { Specializations }\end{array}$ & $\begin{array}{l}\text { Information } \\
\text { technology: } \\
\text { Specializations }\end{array}$ & Others \\
\hline Medicine & 1 & & & & & & & & \\
\hline Languages & $.42^{*}$ & 1 & & & & & & & \\
\hline $\begin{array}{l}\text { Medical and health } \\
\text { Sciences }\end{array}$ & .40 & $.02-$ & 1 & & & & & & \\
\hline Engineering & .49 & .06 & .09 & 1 & & & & & \\
\hline Sport & .17 & $.25-$ & $.23-$ & $.32-$ & 1 & & & & \\
\hline $\begin{array}{l}\text { College of Education: } \\
\text { Specializations }\end{array}$ & .34 & $.08-$ & $.06-$ & $.15-$ & .17 & 1 & & & \\
\hline $\begin{array}{l}\text { College of Sciences: } \\
\text { Specializations }\end{array}$ & .22 & $.21-$ & $.19-$ & $.27-$ & .04 & $.12-$ & 1 & & \\
\hline $\begin{array}{l}\text { Information technolo- } \\
\text { gy: Specializations }\end{array}$ & .16 & $.26-$ & $.24-$ & $.33-$ & $.01-$ & $.18-$ & $.05-$ & 1 & \\
\hline Others & $.42^{*}$ & .00 & .02 & $.07-$ & .24 & .08 & .20 & .25 & 1 \\
\hline
\end{tabular}

\section{DISCUSSION AND CONCLUSION}

Information and communication technology is a new tool in education and learning especially in less developed countries like Jordan. Because of the unprecedented crisis and the threat to public health imposed the COVID-19 virus and thus the national lockdowns, the vast majority of higher educational institutions across the globe had to move to the e-learning to promote the continuity of the teaching-learning process. eLearning programs are not new to the teaching learning process as there are both undergraduate and graduate programs that are completely delivered electronically (e.g. distance learning, online learning, or a combination of both) in many countries across the world especially in developed countries. Thus, the transition to e-learning during the COVID-19 pandemic might not be difficult for these countries and thus could be better adopted and received by both teachers and students in their countries. On the other hand, as this study found, in other countries especially developing ones like Jordan where the technological infrastructure might not be maturely developed, the transition to e-learning might not be well received and adopted. Despite that student respondents involved in this study were overall satisfied with the e-learning they also reported a plethora of difficulties that faced during the elearning process of which most were related to technical problems. Those technical problems might have been caused by the immaturity of electronic technologies in Jordan compared to more developed countries. For instance, a viable internetwork might not be available in many rural and remote areas in the country. Also, both teachers and students in Jordan are not accustomed to e-learning and distance learning which could be another factor affecting the effectiveness of the e-learning as reported by student respondents in this study. Thus, it is essential that policy makers (e.g., Hashemite University administration)in the country take challenges reported by student respondents in this study into consideration when planning for future interventions to enhance technology readiness for elearning programs, improve students' confidence in adopting and transitioning to this new mode, and thus to make elearning more effective.
Results of this study revealed that only students' gender and academic specialty were associated with their evaluation of the effectiveness of the e-Learning. Student's school year, place of residence, grade point average, and academic branch in the Tawjihi were found to have no significant associations with the effectiveness of e-Learning. Students specializing in medicine appear to be more welcoming of e-Learning. Medical students have accepted the e-learning better than students in other specialties and thus reported that e-learning contributed positively to their learning experiences and learning outcomes. This finding could be possibly attributed to differences in performance expectations (e.g., more integration of cognitive activities) and learning climate/social environment between medical school and other schools in the university. In addition, male student respondents have accepted e-learning more smoothly and with patience and evaluated the experience more positively compared to female students. This result could be related to less exposure and the use of technology tools among female students compared to male ones. Further, female students could have suffered more anxiety because of the sudden change from the traditional class room teaching to e-learning which might have thus affected their performance and their satisfaction with the experience as a whole.

\section{FUTURE WORK}

As future work, we will conduct a training sessions for the students to teach them the best techniques on the use of the educational platforms and how to overcome difficulties.

\section{ACKNOWLEDGMENTS}

The authors would like to show their gratitude towards Hashemite University who shared its pearls of wisdom with the authors during different questionnaires and research. The authors are also immensely grateful to the students on their comments and answers to different questionnaires that greatly improved the manuscript.

\section{REFERENCES}

[1] Noor-ul-Amin, S. (2013). An effective use of ICT for education and learning by drawing on worldwide knowledge, research and experience: ICT as a change agent for education (A Literature review). Scholarly Journal of Education.2 (4): 38-45. 
[2] Ali, M., Zhou, L. \&Ieromonachou, P. (2016). User resistance in IT: A literature review. International Journal of Information Management. 36(1): 35-43.

[3] Hrastinski, S. (2008). A study of asynchronous and synchronous eLearning methods discovered that each supports different purposes. EDUCAUSE Quarterly: 31(4).

[4] Santana de Oliveira, M.M., Torres Penedo, A.S. \& Pereira, V. (2018). Distance education: Advantages and disadvantages of the point of view of education and society. Dialogia. 29: 139-152.

[5] Zawacki-Richter, O., Bäcker, E. M., \& Vogt, S. (2009). Review of distance education research (2000 to 2008): analysis of research areas, methods, and authorship patterns. International Review of Research in Open and Distance Learning. 10(6): 21-45.

[6] Burns, M. (2011). Distance Education for Teacher Training: Modes, Models and Methods, Washington, DC: Education Development Center.

[7] Motamedi, V. (2001). A critical look at the use of videoconferencing in United States distance education. Education. 122: 386-394.

[8] L. Moore, J., Dickson-Deane, C. \&Galyen, K. (2010). E-Learning, online learning, and distance learning environments: Are they the same? The Internet and Higher Education. 14: 129-135.

[9] Sangrà, A., Vlachopoulos, D. \& Cabrera, N. (2012). Building an Inclusive Definition of E-Learning: An Approach to the Conceptual Framework. International Review of Research in Open and Distributed Learning, 13:145-159.

[10] S. Bell, B. \& E. Federman, J. (2013). E-Learning in Postsecondary Education. Future of Children. 23 (1): 165-185.

[11] Mohamad Hsbollah, H. \& Md. Idris. K. (2009). E-Learning adoption: the role of relative advantages, trialability and academic specialization. Campus-Wide Information Systems. 26(1): 55-70.

[12] Cheung, R. \& Vogel, D. (2013). Predicting user acceptance of Collaborative technologies: An extension of the technology acceptance model for e-Learning. Computers and Education. 63: 160-175.

[13] Rohayani, A., \&Kurniabudi, Sh. (2015). A literature review: Readiness factors to measuring e-Learning readiness in higher education.ProcediaComputer Science.59: 230-234.
[14] Swanson, A., Davis, B., Parks, O., Atkinson, S., Forde, B. \& Choi, K. (2015). Student engagement, e-connectivity, and creating relationships in the online classroom: emerging themes. International Journal of Instructional Technology and Distance Learning, 12: 66-73.

[15] Talebiana, S., MovahedMohammadia, H. \&Rezvanfara, A. (2014). Information and communication technology (ICT) in higher education: advantages, disadvantages, conveniences and limitations of applying eLearning to agricultural students in Iran. Procedia - Social and Behavioral Sciences, 152: 300-305.

[16] Xu1, D., W. Huang2, W. Wang, H. \&Heales, J. (2014). Enhancing eLearning Effectiveness Using an Intelligent Agent-Supported Personalized Virtual Learning Environment: An Empirical Investigation. Information and Management, 51: 430-440.

[17] Md. Islam, A., Asliza Abdul Rahim, N., Chee Liang, T. \&Momtaz, H. (2011). Effect of Demographic Factors on E-Learning Effectiveness in a Higher Learning Institution in Malaysia. International Education Studies, 4: 112-121.

[18] AudyeCidral, W., Oliveira, T., Di Felice, M. \& Aparicio, M. (2018). ELearning success determinants: Brazilian empirical study. Computers \& Education. 122: 273-290.

[19] Klasnja-Milicevic, A., Vesin, B., Ivanovic, M. \&Budimac, Z. (2011). ELearning personalization based on hybrid recommendation strategy and learning style identification. Computers \& Education. 56: 885-899.

[20] Chen Sun, P., J. Tsai, R., Finger, G., Yang Chen, Y. \& Yeh, D. (2008). What drives a successful e-Learning? An empirical investigation of the critical factors influencing learner satisfaction. Computer and education.50: 1183-1202.

[21] Ssekakubo, G., Suleman, H. \& Marsden, G. (2011). Issues of Adoption: Have E-Learning Management Systems Fulfilled their Potential in Developing Countries?In Proceedings of the South African Institute of Computer Scientists and Information Technologists Conference on Knowledge, Innovation and Leadership in a Diverse, Multidisciplinary Environment, Cape Town, South Africa.: ACM New York, NY, USA, 231-238.

[22] Amin Almaiah, M., Al-Khasawneh, A. \& Al Thunibat, A. (2020). Exploring the critical challenges and factors influencing the e-Learning system usage during COVID-19 pandemic. Education and Information Technologies. $22: 1-20$. 